Skare, M., Porada-Rochon, M., \& Stjepanovic, S. (2021). Testing for Convergence in Competitiveness and Growth in Selected Economies from 1994 to 2020. Journal of Competitiveness, 13(3), 147-164. https:// doi.org/10.7441/joc.2021.03.09

\title{
Testing for Convergence in Competitiveness and Growth in Selected Economies from 1994 to 2020
}

\author{
- Marinko Skare, Małgorzata Porada-Rochon, Sasa Stjepanovic
}

\begin{abstract}
Competitiveness on a small and large scale is necessary for growth. A definitive link between the level of competitiveness and growth has been difficult to prove. One of the primary objectives of economic planning is to promote price and exchange rate stability. Entrepreneurialism and productivity also increase the country's export competitiveness. The aim of this study is to test for the convergence in competitiveness and convergence club existence in selected economies. No previous research had tested for convergence in competitiveness using a nonlinear timevarying factor model. This paper provides an overview on convergence in competitiveness and convergence clubs' existence for 42 countries using quarterly data from 1994q1 to 2020q4 testing on competitiveness. Convergence $\log (t)$ test results show differences in competitiveness between classified convergence clubs. Russia, Brazil, and Turkey are the clubs (groups of countries) that show a transitional path (convergence in competitiveness) that differs entirely from the rest of the sample. Countries with more natural resources and exogenous monetary policies follow a unique development path to competitiveness. We find no evidence of divergence in countries within the clubs. However, we find a club (group of countries) following a clear divergence path from the other countries (Russia, Brazil, and Turkey). Our findings could potentially explain the increase in divergence in competitiveness across countries after the financial crisis of 2008.
\end{abstract}

Keywords: competitiveness, convergence, club clustering, non-linear time-varying factor model, economic growth JEL Classification: C33, C38, D4, O47

Received: April, 2021

(c) (i)

1st Revision: August, 2021

Accepted: August, 2021

\section{INTRODUCTION}

Competitiveness, both on the micro and macro level, is crucial to economic growth. It is a complex phenomenon influenced by many factors. The macroeconomic environment (price and exchange rate stability) is undoubtedly one of them. Innovation and productivity on firms' level also drive a country's competitiveness resulting in increasing export competitiveness. Institutional framework (legal and economic) also dictates firms' and country's competitiveness on an international scale. The study of competitiveness is a topic under intense research in the field of economics. This is generally accepted in the literature from which we can conclude 
competitiveness as a necessary condition for economic growth.

The reason lies in the complexity of competitiveness that is broadly defined in the literature. To investigate the hypothesis that competitiveness is important for long-term growth sustainability in emerging economies, (Tahir \& Tahir, 2019) use the Global Competitive Index (GCI) to conduct the test. This study provides econometric evidence that competitiveness positively affects economic growth. Given the comparisons shown here, one can conclude that relative productivity levels tend to move in tandem with relative labor costs, which is why labor costs between countries are more equal than absolute productivity levels (Ark et al., 2005). Economic integration has an impact on trade competitiveness, as in the case of BRICS countries (Thazhugal Govindan Nair, 2020). This research demonstrates the effects of economic integration on trade and investment performance and assesses trade competitiveness in member countries. Economic integrations, such as BRICS, change the economic development policy and structure of country members improving foreign direct investments (FDI) inflow and trade competitiveness. There has been relatively little effort aimed to study convergence in competitiveness across countries. No previous study had tested for convergence in competitiveness using a nonlinear time-varying factor model.

It is essential to understand the full extent of convergence dynamics as the primary research aim of this article. One of the most important findings relates to the competitiveness convergence analysis lacking in previous studies. This plays an important role in the improvement of competitiveness understanding. To study convergence and convergence clubs in competitiveness, we use nominal and real effective exchange rates. This article uses quarterly data from 1994q1 to $2020 \mathrm{q} 4$ for 42 countries. The main database we use in the study is the (European Commission Directorate-General for Economic and Financial Affairs, 2021).

This paper provides an overview of convergence in competitiveness and convergence clubs' existence for 42 countries using quarterly data from 1994q1 to 2020q4. To test the convergence hypothesis in competitiveness, we adopt the result-oriented approach (Hildebrandt \& Silgoner, 2007) or the price competitiveness approach. To estimate competitiveness convergence, this study uses both nominal effective exchange rate (NEER) and real effective exchange rate (REER) from (European Commission - Directorate-General for Economic and Financial Affairs, n.d.). We adopt the methodological framework developed by (Phillips \& Sul, 2007a, 2009) and (Schnurbus et al., 2017), using the Stata package developed by (Du, 2017). In this article, terms (NEER and REER) will be used to measure a country's external competitiveness. We have data from 1994 to 2020, testing convergence hypothesis on external competitiveness indicators to accept or discard the hypothesis of competitiveness convergence and various convergence clubs' existence. Research in this area is usually carried out using time series or panel data approach. The study is inspired by similar work of (Phillips \& Sul, 2007a, 2009) and (Schnurbus et al., 2017) in economic growth convergence, cost of living, house prices. This is an active and open research area with limited research (Drastichová \& Ostrava, 2012; Baltgailis, 2019; Mazzanti et al., 2020) testing for convergence in external competitiveness indicators.

This study contributes to the literature on convergence in competitiveness by using modern panel club convergence and clustering procedure developed by (Phillips \& Sul, 2007b). Such an approach overcomes bias issues (stationarity, linearity) and conditions limiting research on 
convergence in competitiveness.

The first part of this paper introduces the competitiveness concept and importance on the micro and macro level. The second part discusses prior research on competitiveness and the research gap on convergence in competitiveness. This is followed by section 3, which explains research objectives, methodology and data. The following section (results and discussion) interprets the results and compares those to previous research and expected outcomes. We summarized the article findings on competitiveness convergence in conclusion.

\section{THEORETICAL BACKGROUND}

Competitiveness is closely associated with economic growth on the micro and macro level. It is a crucial factor behind the economic growth convergence/divergence theory. In this section, we review various approaches available in the literature for competitiveness. Competitiveness has been an important topic of study in the literature for many years. However, competitiveness convergence theory (hypothesis) offers limited (almost none) comparative research on this topic. No previous study has studied, supported, or rejected the competitiveness convergence hypothesis observed in this article. In the study (Bhawsar \& Chattopadhyay, 2015), competitiveness has gone a long way from its birth by the classical economist Adam Smith (Smith, 2000) to Michael Porter (Porter, 1990, 1998, 2011) and others (Huggins \& Izushi, 2015), who presented the extended versions of the Diamond model.

The biggest obstacles to the loss of country's competitiveness in the international market are challenges of productivity, ineffective investment patterns in research and development ( $\mathrm{R} \&$ D), widening trade deficits, technological development caught by other nations, losing ground in product quality, and lack of a strong political and legal environment (Bhawsar \& Chattopadhyay, 2015).

Competitiveness has been widely explored on the macro level. A study of Radaev (2018) on Russia shows that fifteen years after liberalization, the state has returned to a highly competitive industry that was essentially deregulated and privatized at the beginning of the economic change. Price competitiveness is measured in (Sato et al., 2020), studying the link between export price competitiveness and regional supply chains in Asia. Economic policy and institutional framework are important for competitiveness in Latin America (Garcia Martinez et al., 2019). Labor productivity in Russia significantly influences competitiveness according to the study of (Fedulova et al., 2019) and Latvia (Korshenkov, \& Ignatyev, 2020). Economy structure and strength are crucial for promoting competitiveness (Aiginger \& Vogel, 2015). Institutions and institutional quality are vital for achieving international competitiveness (Buitrago R. \& Barbosa Camargo, 2021). Corruption is a significant constraint for competitiveness (Ulman, 2013). Economic freedom significantly affects national competitiveness (Bujancă \& Ulman, 2015). Human resources in Kazakhstan present a significant connection to the level of competitiveness (Caurkubule et al., 2020).

Studies on industry-level competitiveness determinants are included (Meleo, 2014). Competition network as a source of competitiveness (Wang \& Gao, 2020) as well as high-tech sectors (Braja \& Gemzik-Salwach, 2019) are also part of it. Institutional arrangements have a key role 
in the innovation system in Japan (Kwon \& Motohashi, 2017). Same holds for the shipping industry in Indonesia (Gena et al., 2020). Corporate governance in China is crucial to promote competitiveness (Yang, 2014; Lin et al., 2015). Productivity and competitiveness show double feedback (Baumann et al., 2019)

Firms' level studies on competitiveness follow (Carney et al., 2017) with teamwork management as the promoting factor (Černevičiūtè, \& Strazdas, 2018). Entrepreneurship is directly linked to competitiveness (Veiga et al., 2020) as firms' flexibility (Ni et al., 2021). (Falciola et al., 2020). Labor productivity on firms' level is also crucial for competitiveness (Toan et al. 2020), and corruption is a limiting factor (Skrynkovskyy et al., 2021). Measuring competitiveness on a firm level (Pattanasing et al., 2021) and firms' organizational characteristics have a significant role in competitiveness (Sun \& Lee, 2019).

The role of the state in competitiveness is explored in Russia, an alternative model of governance, which was different from previous examples of industrial and corporatist policies (Radaev, 2018). In modern economies, one way to realize the benefits of greening the entire supply chain is to highlight the opportunity for individual customers and industries to increase their environmental sustainability (Korhonen et al., 2015). The role of corporate governance in competitiveness, according to the latest research, good corporate governance leads to longer-term value, but not in non-competitive industries (Yu et al., 2017). Export-price impact on competitiveness, Real effective exchange rate (REER) remain an essential factor in trade competitiveness (Sato et al., 2020). Entrepreneurship retains a crucial role in promoting competitiveness and growth. The results show that GDP growth and population growth in start-up density are statistically significant (Veiga et al., 2020). Institutional economics is an important determinant for promoting competitiveness. Latin America's economies have experienced increased prosperity in recent decades (Cárdenas et al., 2018). The paper presents two alternative theories to investigate the interaction between institutions and productivity: social capital and the resource environment (Buitrago \& Barbosa Camargo, 2021).

As for competitiveness in high-tech sectors, there is a correlation between investment in R\&D and export in the high-tech sectors (Braja \& Gemzik-Salwach, 2019). Productivity and competitiveness show a close association demanding to be explored in more detail (Baumann et al., 2019). If new-to-outcome and price competitiveness are desired, economic structure and capabilities are more important to this outcome than price competitiveness, which is a wellknown study among scientists (Aiginger \& Vogel, 2015). Industrial clusters also promote competitiveness, as in the case of Visegrad group countries. Intra-industry trade is more resilient to foreign conditions outside the focus area (Molendowski, 2014).

\section{RESEARCH OBJECTIVE, METHODOLOGY AND DATA}

The aim of this study is to test for the convergence and convergence club in selected economies.

The database contains information on NEER (Nominal Effective Exchange Rate) is the weighted average of bilateral nominal exchange rates compared to the currencies of selected trading partners. The data are expressed as $\%$ change over three years and $\%$ over one year. Real Effective Exchange Rate (REER) aims to assess a country's price or cost competitiveness compared to its 
main competitors in international markets. Changes in cost and price competitiveness depend not only on exchange rate movements but also on cost and price trends. The specific (REER) for the macroeconomic imbalance procedure is deflated by consumer price indices compared to a panel of 42 countries (double export weights are used to calculate (REERs), which reflect not only competition in the home markets of the various competitors but also competition in export markets elsewhere). Positive (REER) value means real appreciation indicating a loss in the country's trade competitiveness. Data are expressed as the percentage change of the real effective exchange rate (REER) over three years after consumer price index deflators compared to 42 trading partners.

The motive and theoretical background behind using (NEER) and (REER) as country's competitiveness indicators (external) lies in the fact that we wanted to assess overall convergence. Data supporting this point are not only limited but also indirect. To measure convergence for 42 countries, using data following result-oriented approach to competitiveness (Hildebrandt \& Silgoner, 2007). Besides measuring results, it is crucial to examine indicators of international competitiveness like export growth, market share in the global economy, real exchange rate, real per capita income, current account, and country presence in high-technology sectors. These benchmarks show a country's performance in international competition, but they cannot predict future events or show a country's competitiveness.

The determinant-oriented approach (Hildebrandt \& Silgoner, 2007) assumes a correlation between specific determinants and a country's competitiveness; the inference holds they are associated. Factors like the costs for the production factors, labor, capital, technology, infrastructure, and business conditions all contribute to a location's cost. To measure convergence in selected countries, the available data is limited and present only after 1990. Although helpful in generating knowledge on sources of competitiveness and determinants, this approach has the disadvantage of not taking into account technology gaps. Former socialist countries in 1990 were lagging technologically for 20-30 years (in innovation and technological advancement) behind market economies. Using a determinant-oriented approach and not considering this fact, high technological divergence, would result in testing competitiveness convergence bias. For this reason, and since the main aim of this study is to test for convergence and convergence clubs in competitiveness and not explore competitiveness determinants, we choose the result-based approach for convergence testing.

Following (Phillips \& Sul, 2007, 2009), we use their model for convergence testing on the competitiveness of the form

$\log C_{i t}^{o}=\delta_{i t}^{o} \log C_{t}^{o}+e_{i t}$

where $\log C_{\mathrm{it}}$ is the competitiveness indicator $=\log (\mathrm{NEER}), \log (\mathrm{REER})$ for the ith country, $\log C_{t}^{o}$ as common (NEER), (REER) trend across countries with idiosyncratic trade cycle components $\mathrm{e}_{\mathrm{it}}$. Testing the null hypothesis of no convergence in competitiveness follows

$\log \left(\frac{H_{1}}{H_{t}}\right)-2 \log L(t)=\hat{c}+\hat{b} \log t+\hat{u}_{t}$

for details on convergence testing and proofs, see (Phillips \& Sul, 2007, 2009). 
Tab. 1 - List of countries in the sample 1994q1 to 2020q4. Source: European Commission Directorate-General for Economic and Financial Affairs, 2021

\begin{tabular}{|l|l|l|}
\hline \multicolumn{2}{|l|}{ Countries } & Croatia \\
\hline Justralia & Netherlands & Germany \\
Austria & Cyprus & Slovakia \\
Korea & New Zealand & Greece \\
Belgium & Czech Republic & Slovenia \\
Latvia & Norway & Hong Kong \\
Brazil & Denmark & Spain \\
Lithuania & Poland & Hungary \\
Bulgaria & Estonia & Sweden \\
Luxembourg & Portugal & Ireland \\
Canada & Finland & Switzerland \\
Malta & Romania & Italy \\
China & France & Turkey \\
Mexico & Russia & United Kingdom \\
\hline
\end{tabular}

Notes: Database accessed on January 18, 2021.

Table 1 list the countries in the sample we use in this study. Countries were selected based on data availability (available competitiveness indicators) and methodology as defined in the (European Commission - Directorate-General for Economic and Financial Affairs, 2021). We use this statistical database since it offers balanced data on (NEER) and (REER) with a balanced panel sample as a requirement for running convergence test in competitiveness for convergence clubs. To form club clusters, we use (Phillips \& Sul, 2007a, 2007b, 2009) procedures and tests. The t-test for the null hypothesis of convergence in competitiveness takes the form

$\mathrm{H}_{0}: \delta_{\mathrm{i}}=\delta$ and $\alpha \geq 0$

with $\log \mathrm{t}$ regression model

$$
\begin{gathered}
\log \left(\frac{H_{1}}{H_{t}}\right)-2 \log \{\log (t)\}=a+b \log (t)+\varepsilon_{t} \\
\text { for } t=[r T]_{1}[r T]+1, \ldots, T \text { with } r>0
\end{gathered}
$$

and $\mathrm{H}_{\mathrm{it}}$

$H_{t}=N^{-1} \sum_{i=1}^{N}\left(h_{i t}-1\right)^{2} \rightarrow 0, t \rightarrow \infty$

$h_{i t}=\frac{\log y_{i t}}{\left(N^{-1} \sum_{i=1}^{N} \log y_{i t}\right)}$

Running the model above, we group countries in initial convergence clubs based on (NEER) and (REER) competitiveness indicators. To form final convergence clubs, we test for club merging ruining the t-test for all pairs of initial convergence clubs. Finally, we check for crosssectional means across convergence clubs using relative transition parameters (plotting relative 
transition curves across clubs). Plots of relative transition parameters across clubs displays trend of convergence or divergence in the and between clubs. Data entering t-test are pre-filtered using (Hodrick \& Prescott, 1997) of the form

$\operatorname{m}_{\left\{g_{t}\right\}_{t-1}^{T}}\left\{\sum_{t=1}^{T}\left(y_{t}-g_{t}\right)^{2}+\lambda \sum_{t=1}^{T}\left[\left(g_{t}-g_{t-1}\right)-\left(g_{t-1}-g_{t-2}\right)\right]^{2}\right\}$

with the smoothing parameter $\chi$ and trend component gt (Hamilton, 2018).

The analysis was carried out using the (Du, 2017) Stata package and (Sichera \& Pizzuto, 2019) R package.

\section{RESULTS AND DISCUSSION}

First, we test if the convergence hypothesis in competitiveness using (NEER) and (REER) competitiveness indicators and following procedure (Phillips \& Sul, 2007a, 2007b, 2009).

Table 2 reports the $\log (\mathrm{t})$ regression coefficient, standard errors, and t-statistic $\log (\mathrm{t})$.

Tab. 2 - Log (t) Convergence Test Results in Competitiveness. Source: own research

\begin{tabular}{|l|l|l|l|}
\hline Variable & Coeff & Standard error & T-stat \\
\hline$($ NEER $)$ & & & \\
\hline $\log (t)$ & -2.3227 & 0.2440 & $-9.1588^{*}$ \\
\hline$($ REER $)$ & & & \\
\hline $\log (t)$ & -0.6826 & 0.1596 & $-4.2770^{*}$ \\
\hline
\end{tabular}

Notes: *Reject the null hypothesis of competitiveness convergence at the $5 \%$ level.

Since the value of the $t$ statistics (NEER) and (REER) is smaller than test statistics $t_{\gamma} \leq-1.65$ the null hypothesis of convergence in competitiveness is rejected at the $5 \%$ level for the whole sample. Despite economic and ICT globalization, institutional associations, the economic growth, we find no evidence to support the hypothesis of convergence in competitiveness for the observed countries. Competitiveness differs significantly across the countries in the sample.

After rejecting the competitiveness convergence hypothesis for the whole sample (all countries), we identify convergence clubs (a set of countries converging in competitiveness). Following initial convergence clubs (set up from the 42 countries), we test for possible club merging to obtain the final convergence club structure for (NEER) and (REER).

Using the convergence test modeling, we identify three convergence clubs from the sample of 42 countries using (NEER) as a competitiveness indicator.

Figure 1 lists the identified convergence clubs and countries clustered according to the $\log (\mathrm{t})$ test results. 
Tab. 3 - Convergence Club Classification (NEER). Source: own research

\begin{tabular}{|c|c|c|c|c|c|}
\hline \multicolumn{2}{|c|}{$\begin{array}{l}\text { Initial classification } \\
\qquad \widehat{\boldsymbol{\gamma}}(\mathrm{SE} \text { of } \widehat{\boldsymbol{\gamma}})\end{array}$} & \multicolumn{2}{|c|}{$\begin{array}{l}\text { Tests of club merging } \\
\qquad \widehat{\boldsymbol{\gamma}}(\mathrm{SE} \text { of } \widehat{\boldsymbol{\gamma}})\end{array}$} & \multicolumn{2}{|c|}{$\begin{array}{l}\text { Final classification } \\
\qquad \widehat{\boldsymbol{\gamma}}(\mathrm{SE} \text { of } \widehat{\boldsymbol{\gamma}})\end{array}$} \\
\hline Club 1 [33] & $\begin{array}{r}0.168 \\
(0.169)\end{array}$ & & & Club 1 [33] & $\begin{array}{c}0.168 \\
(0.169)\end{array}$ \\
\hline Club 2 [6] & $\begin{array}{c}0.948 \\
(0.155)\end{array}$ & $\begin{array}{c}\text { Club } 1+2 \\
-0.7646^{*} \\
(0.1748)\end{array}$ & & Club 2 [6] & $\begin{array}{c}0.948 \\
(0.155)\end{array}$ \\
\hline Club 3 [3] & $\begin{array}{c}0.635 \\
(0.568)\end{array}$ & & $\begin{array}{c}\text { Club } 2+3 \\
-1.9505^{*} \\
(0.1749)\end{array}$ & Club 3 [3] & $\begin{array}{c}0.635 \\
(0.568)\end{array}$ \\
\hline
\end{tabular}

Notes: *Reject the null hypothesis of growth convergence at the $5 \%$ level. The number in brackets indicates the number of countries in identified convergence group.

Using nominal effective exchange rate, we identify three distinct convergence clubs. Clubs merging test results (Table 3) show no evidence of possible club merging for three initial convergence clubs. Therefore, initial convergence clubs are (according to the test results of club merging) also a final classification form. We can observe most countries use pegging country's exchange rates to main trading partners' currencies. That is particularly true for the countries with a history of high inflation, ex-communist. Nations obey the targeting exchange rate policy (inflation differentials) and factor costs management (wage moderation). However, wage moderation varies significantly across countries having a different impact on productivity and competitiveness. Exchange rate policy, as our results show, for a majority of the countries in the sample is not effective in supporting trade competitiveness - pegged to EUR (or EUR as national currency) or US\$. Thus, unit labor costs and wage policy dominate in the competitiveness discussion. It is interesting to observe the clubs 2 and 3 with countries still using leverage on their exchange rate to support competitiveness.

Since 2005, we can notice a strong convergence trend in competitiveness for the countries in the club 1. The financial crisis of 2008 had an impact on individual country's competitiveness resulting in a limited divergence in (NEER). This is clearly visible after the point at which transition curves were conveying (converging to a single point). However, besides the crisis of 2008 and pandemics, a strong convergence in competitiveness for the club 1 remains.

That was not the case for the convergence club 2. Since 1994q1, there is visible a strong divergence in competitiveness between countries in the club 2. Since 2000 and the great moderation, countries within the club have started to converge in (NEER), reaching the convergence points around 2008. After the financial crisis, Japan started to diverge together with Mexico while the rest of the countries still retain a level of convergence in competitiveness. 


\begin{tabular}{|c|c|}
\hline Club 1 & $\begin{array}{c}\text { Austria, Belgium, Bulgaria, China, Croatia, Cyprus, Czech Republic, Denmark, } \\
\text { Estonia, Finland, France, Germany, Greece, Hong Kong (China), Ireland, Italy, } \\
\text { Korea, Lativa, Lithuania, Luxemburg, Malta, Netherlands, New Zeland, Poland, } \\
\text { Portugal, Romania, Slovakia, Slovenia, Spain, Sweden, Switzerland, United } \\
\text { Kingdom, USA }\end{array}$ \\
\hline Club 2 & Australia, Canada, Hungary, Japan, Mexico, Norway \\
\hline Club 3 & Brazil, Russia, Turkey \\
\hline
\end{tabular}

Fig. 1 - Clustering Analysis and Convergence Clubs in Competitiveness (NEER) from 1994q1 to $2020 q 4$. Source: own research

Relative transition curves for Club 3 share the same trends as in Club 2. After the transition phase and divergence, countries start to convey to a joint path reaching convergence point around 2008. After 2008, countries show limited divergence in (NEER), particularly strong in Turkey.

Clubs 1 and 2 share a similar transition path (competitiveness) from 1994Q1 to 2020 Q4. However, Club three, with Russia, Brazil and Turkey, shows to follow a divergent path to Clubs 1 and 2. This is an interesting fact since Brazil is among emerging countries, and both Russia and Turkey are candidates to claim high growth rates until 2040 (Figure 2).

To check the robustness of the result, but also following (Hildebrandt \& Silgoner, 2007) suggestion for the adjusted measure of (NEER), we use (REER) for convergence test. As an alternative to (NEER), (REER) is suggested to account for relative prices and cost differences between countries combining price, cost, and exchange rate (inflation differentials). Below we present convergence test results for the same sample using (REER) as a competitiveness indicator.

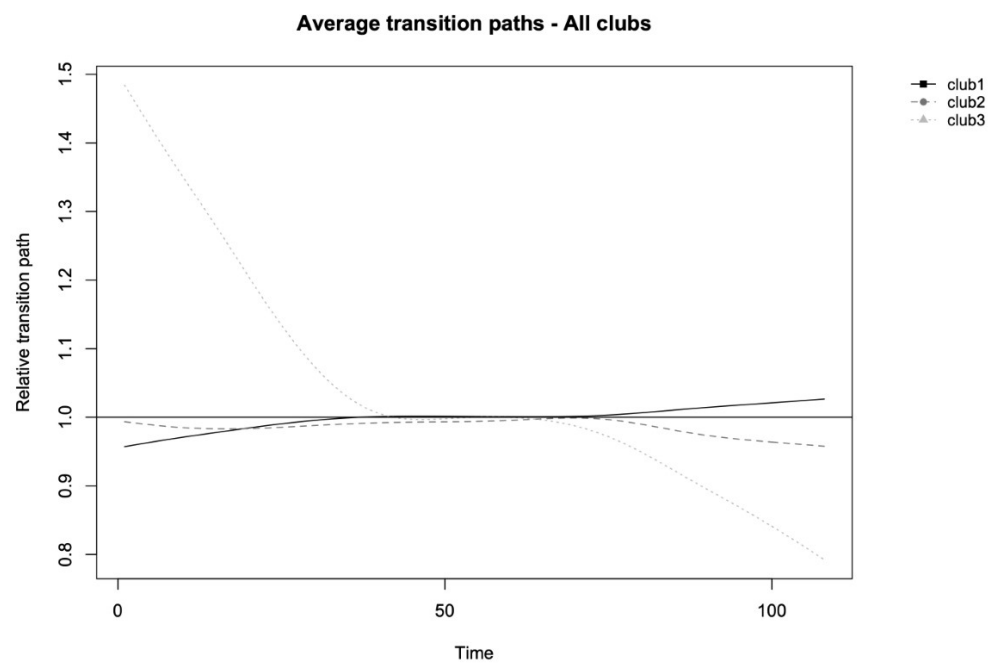

Fig. 2 - Average Transition Paths - All Clubs (NEER). Source: own research 
Figure 2 shows the average transition path for all clubs identified in the study. We observe a strong convergence in competitiveness between the clubs. Club 3 with Brazil, Russia, and Turkey after 2015 shows a divergence in competitiveness indicators. The dynamics of competitiveness in these countries after 2015 significantly changed, leading to divergence behavior from the rest of the countries in the study.

Using (REER) as an indicator for competitiveness, we identify two convergence clubs (as opposed to three using NEER). The results are somewhat expected since (REER) as an indicator of competitiveness, considers inflation differentials with leading trading partners. Because of the monetary union of the EU and inflation targeting policy accepted across economies, inflation within a country is moving along the same path as in the main trading partners. Because of that, when we correct (NEER) for inflation differentials to get (REER) after running the log $(t)$ convergence test, we have just two convergence clubs.

Tab. 4 - Convergence Club Classification (REER). Source: own research

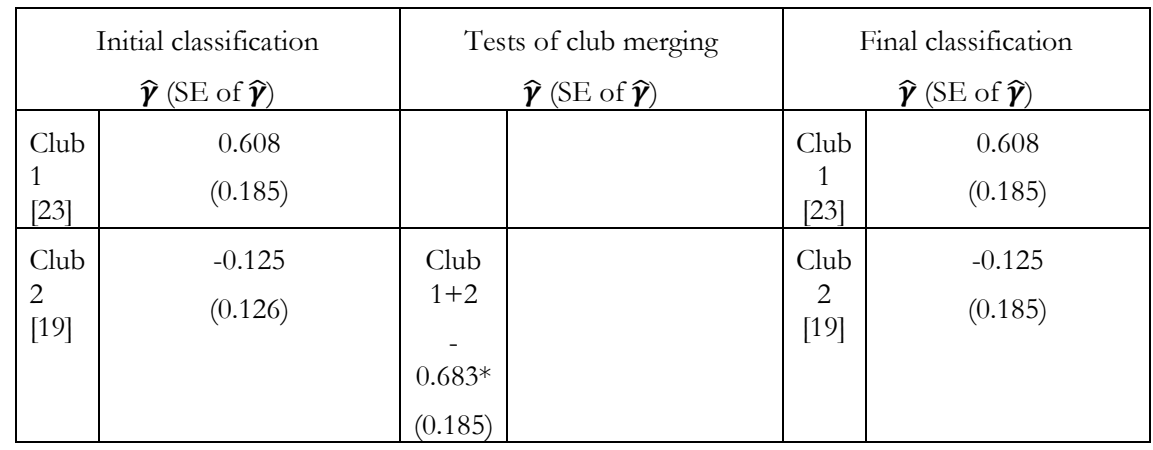

Notes: *Reject the null hypothesis of growth convergence at the $5 \%$ level. The number in brackets indicates the number of countries in identified convergence group.

Club merging test results show initial clubs cannot be merged, so the final classification follows the initial one (Table 3). Figure 3 displays final convergence clubs in competitiveness using (REER). 


\begin{tabular}{|c|c|}
\hline Club 1 & $\begin{array}{c}\text { Austria, Belgium, Bulgaria, China, Czech Republic, Estonia, Finland, Germany, } \\
\text { Hong Kong (China), Korea, Lativa, Lithuania, Luxemburg, Malta, Netherlands, } \\
\text { New Zeland, Portugal, Romania, Slovakia, Slovenia, Switzerland, United } \\
\text { Kingdom, USA }\end{array}$ \\
\hline Club 2 & $\begin{array}{c}\text { Australia, Brazil, Canada, Croatia, Cyprus, Denmark, France, Greece, Hungary, } \\
\text { Ireland, Italy, Japan, Mexico, Norway, Poland, Russia, Spain, Sweden, Turkey }\end{array}$ \\
\hline
\end{tabular}

Fig. 3 - Clustering Analysis and Convergence Clubs in Competitiveness (REER) from 1994q1 to $2020 q 4$.

Source: own research

Now, we have two convergence clubs after (REER) convergence testing. The results are expected; maybe a small surprise is Germany in the first and not the second convergence clubs. Looking at the clubs' relative transition curves could explain the position of Germany in the first convergence club. After initial divergence, all countries in the club 1 converged to a point (around the financial crisis 2008). After that point, divergence is present again but to a limited extent, with club convergence remaining stable. Germany's position after unification and Euro introduction are not surprising anymore since Germany is the most important European trade partner for countries outside EU in the club 1.

Relative transition curves for the club 2 reveal information about convergence in the club containing 19 countries. We observe a similar initial transition pattern as in the club 1 . However, after converging to a point (also we note some divergence around the convergence point), the divergence is more spread than in the club 1 . We can observe the most significant divergence in Denmark, Brazil, Russia, and Japan.

A clear divergence path in (REER) is visible between the two clubs. This is a clear signal of the competitiveness divergence between countries in the two clubs. The divergence is even stronger compared to the average transition path for (NEER).

These results suggest (for the total sample) that a significant divergence in competitiveness still exists. This could possibly be a result of the divergences in the economic growth rates and technological progress gap. Convergence $\log (\mathrm{t})$ test results show convergence hypothesis in competitiveness is not holding for this study sample. There is a noticeable difference between the level of competitiveness (measured by NEER and REER) across countries. Differences in the competitiveness level might be attributed to the business environment, energy (Emir et al., 2019; (Škare et al., 2021), technology and infrastructure, factors of production (capital and labor) (Prasetyo \& Kistanti, 2020), labor costs (Ark et al., 2005), labor markets (Negara, 2018), economic associations (Thazhugal Govindan Nair, 2020) and monetary unions (Landesmann \& Leitner, 2015; Hildebrandt \& Silgoner, 2007; Gardiner, 2003). 


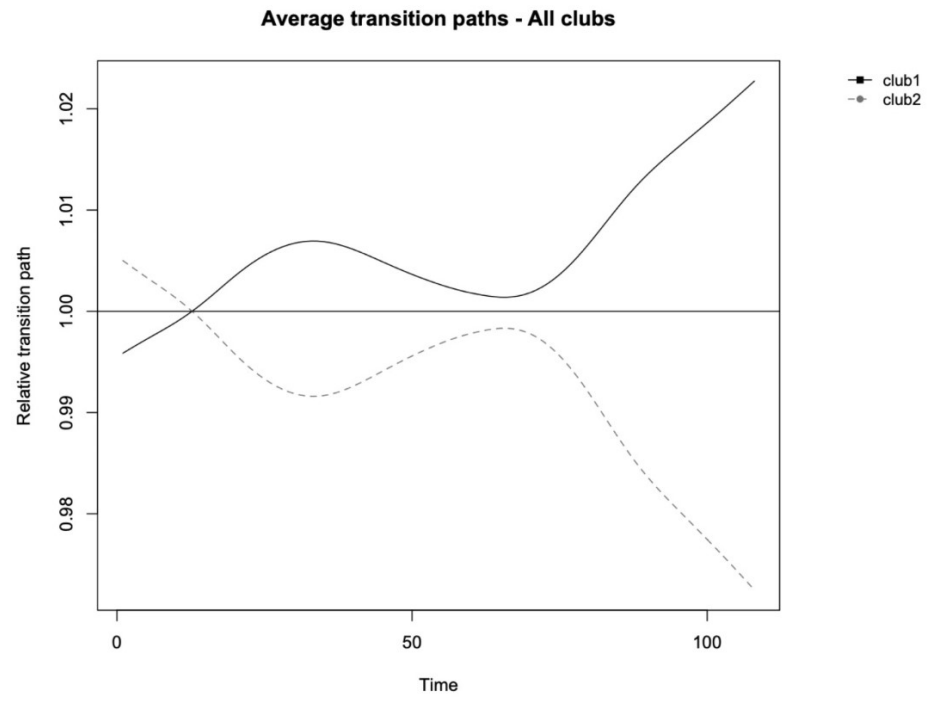

Fig. 4 - Average Transition Paths - All Clubs (REER). Source: own research

We identify three distinct convergence clubs using (NEER) and two convergence clubs using (REER). Log ( $t$ ) convergence test results show convergence hypothesis in competitiveness hold for countries identified in the convergence clubs. Countries within identified convergence clubs tend to converge in competitiveness level, supporting the convergence hypothesis. Relative transition curves for identified convergence clubs support these results. No divergent group of countries is found within the convergence clubs, no marks of divergence in competitiveness within the clubs. However, a distinct club with a group of countries Russia, Brazil and Turkey emerge as a group of countries diverging (decoupling) in competitiveness with other countries and convergence clubs. Further studies are required to analyze and understand the determinants of decoupling in competitiveness for Russia, Brazil, and Turkey. Understanding factors behind the decoupling could help us understand the nature and main determinants behind competitiveness and convergence.

Our study provides empirical evidence on convergence in competitiveness. Russia, Brazil, and Turkey follow a divergence path in the sample. Comparing to the growing convergence, we can observe convergence in competitiveness is particularly strong. That evidence points us to the direction that countries achieve more convergence in competitiveness (through similar monetary and fiscal policies) to growth policies (growth convergence). Globalization and financial crisis have a significant impact on the competitiveness convergence path. Even without a new and global Gold standard or Bretton Wood system, competitiveness convergence can be achieved.

\section{CONCLUSION}

Competitiveness is an important determinant of economic growth. Competitiveness is a complex phenomenon, demanding complex methods to measure it and understand its role in 
economic growth. Like the convergence hypothesis in economic growth, this paper checks for the convergence hypothesis in competitiveness.

In summary, we have shown that clubs' convergence in competitiveness (measured by NEER and REER) exists. Convergence $\log (t)$ test results show divergence in competitiveness is present between classified convergence clubs. The results conclude that convergence in competitiveness across countries exists within a specific classified club, and divergence in competitiveness exists between clubs. We find no evidence of divergence in countries within the clubs. However, we see a club (group of countries) following a clear divergence path from other countries. Russia, Brazil and Turkey are the club (group of countries) showing transitional path (convergence in competitiveness) completely different from the rest of the sample. This is an interesting finding, and it could be hypothesized that countries with more natural resources and exogenous monetary policy follow a different development path for competitiveness. There is a broad interest and literature base for research on the competitiveness convergence hypothesis. We suggest that future studies should examine the nature of the competitiveness decoupling in these three economies. This work can be used as a reference for future studies on convergence in competitiveness. Future work is planned to study an international panel (sample with 150 countries) more in depth and over 1960-2020. It is essential that panel limitations of this study are considered in future studies.

These findings have two important practical implications for policymakers and practitioners. First, it allowed policymakers to closely monitor the level of competitiveness in an economy to stimulate its long-run, sustainable growth. Managers and owners having full information on competitiveness dynamics can improve their decision-making processes on business investments, financial sources, interest rates risk and risk management to sustain firms' future growth. This is of particular interest in applications where policymakers set up guidelines to develop the country's competitiveness and practitioners to assure the firm's competitive position on the market. These findings may be a direct consequence of globalization, financial cycles, world efforts to search for a new Gold standard or Bretton Woods system. Our findings could potentially explain the increase in divergence in competitiveness across countries after the financial crisis of 2008. This is where the novelty of this work lies in studying the convergence hypothesis in competitiveness. This research is hoping to contribute to the direction of broadening the knowledge of convergence in competitiveness. As expected, the major contribution of this study comes from proving the convergence hypothesis in competitiveness and identifying convergence clubs. The discrepancy observed (decoupling in competitiveness) for Russia, Brazil and Turkey deserve further study for future contributions to competitiveness and trade.

\section{References}

1. Aiginger, K., \& Vogel, J. (2015). Competitiveness: from a misleading concept to a strategy supporting Beyond GDP goals. Competitiveness Review, 25 (5), 497-523. https://doi.org/10.1108/ CR-06-2015-0052

2. Ark, B. van, Stuivenwold, E., \& Ypma, G. (2005). Unit labour costs, productivity and international competitiveness. Groningen Growth; Development Centre, University of Groningen. 
3. Baltgailis, J. (2019). The issues of increasing the effectiveness of teaching comparative economics. Insights into Regional Development, 1 (3), 190-199. https://doi.org/10.9770/ $\operatorname{ird} .2019 .1 .3(1)$

4. Baumann, C., Cherry, M., \& Chu, W. (2019). Competitive Productivity (CP) at macro-mesomicro levels. Cross Cultural \& Strategic Management, 2 (26), 118-144. https://doi.org/10.1108/ CCSM-08-2018-0118

5. Bhawsar, P., \& Chattopadhyay, U. (2015). Competitiveness: Review, Reflections and Directions. Global Business Review, 16 (4), 665-679. https://doi.org/10.1177/0972150915581115

6. Braja, M., \& Gemzik-Salwach, A. (2019). Competitiveness of high-tech sectors in the European Union: A comparative study. Journal of International Studies, 12 (2), 213-227. https:// doi.org/10.14254/2071-8330.2019/12-2/13

7. Buitrago, R. E., \& Barbosa Camargo, M. I. (2021). Institutions, institutional quality, and international competitiveness: Review and examination of future research directions. Journal of Business Research, 128, 423-435. https://doi.org/10.1016/j.jbusres.2021.02.024

8. Bujancă, G. V., \& Ulman, S. R. (2015). The Impact of the Economic Freedom on National Competitiveness in the Main Economic Power Centres in the World. Procedia Economics and Finance, 20, 94-103. https://doi.org/10.1016/s2212-5671(15)00052-0

9. Cárdenas, G., García, S., \& Salas, A. (2018). Institutional framework and governance in Latin America. International Journal of Emerging Markets, 13 (5), 1088-1107. https://doi.org/10.1108/ IJoEM-09-2017-0371

10. Carney, M., Duran, P., van Essen, M., \& Shapiro, D. (2017). Family firms, internationalization, and national competitiveness: Does family firm prevalence matter? Journal of Family Business Strategy, 8 (3), 123-136. https://doi.org/10.1016/j.jfbs.2017.06.001

11. Caurkubule, Z. L., Kenzhin, Z. B., Bekniyazova, D. S., Bayandina, G. D., \& Dyussembekova, G. S. (2020). Assessment of competitiveness of regions of the Republic of Kazakhstan. Insights into Regional Development, 2 (1), 469-479. http://doi.org/10.9770/IRD.2020.2.1(6)

12. Černevičiūtè, J., \& Strazdas, R. (2018). Teamwork management in Creative industries: factors influencing productivity. Entrepreneurship and Sustainability Issues, 6 (2), 503-516. http://doi. $\operatorname{org} / 10.9770 /$ jesi.2018.6.2(3)

13. Drastichová, M., \& Ostrava, V. T. (2012). The relations of real and nominal convergence in the EU with impacts on the euro area participation. Ekonomická revue - Central European Review of Economic Issues, 15 (2), 107-122.

14. Du, K. (2017). Econometric Convergence Test and Club Clustering Using Stata. The Stata Journal: Promoting Communications on Statistics and Stata, 17 (4), 882-900. https://doi. org/10.1177/1536867X1801700407

15. Emir, F., Balcilar, M., \& Shahbaz, M. (2019). Inequality in carbon intensity in EU-28: an analysis based on club convergence. Environmental Science and Pollution Research, 26 (4), 33083319. https://doi.org/10.1007/s11356-018-3858-1

16. European Commission - Directorate-General for Economic and Financial Affairs. (2021). Statistics Eurostat. Retrieved from: https://ec.europa.eu/eurostat/databrowser/view/tipser11/ default/table?lang=en 
17. European Commission - Directorate-General for Economic and Financial Affairs. (2021). Statistics Eurostat. Retrieved from: https://ec.europa.eu/eurostat/databrowser/view/tipser11/ default/table?lang=en

18. Falciola, J., Jansen, M., \& Rollo, V. (2020). Defining firm competitiveness: A multidimensional framework. World Development, 129, 104857. https://doi.org/10.1016/j.worlddev.2019.104857

19. Fedulova, I., Voronkova, O., Zhuravlev, P., Gerasimova, P., Glyzina, M., \& Alekhina, N. (2019). Labor productivity and its role in the sustainable development of economy: on the example of a region. Entrepreneurship and Sustainability Issues, 7 (2), 1059-1073. http://doi. org/10.9770/jesi.2019.7.2(19)

20. Garcia Martinez, M., Zouaghi, F., Garcia Marco, T., \& Robinson, C. (2019). What drives business failure? Exploring the role of internal and external knowledge capabilities during the global financial crisis. Journal of Business Research, 98, 441-449. https://doi.org/10.1016/j. jbusres.2018.07.032

21. Gardiner, B. (2003). Regional Competitiveness Indicators for Europe - Audit, Database Construction and Analysis. Cambridge: Cambridge Econometrics.

22. Gena, B., Arief, D., Tridoyo, K., \& Nimmi, Z. (2020). Competitive advantage improvement strategy of container shipping industry: Case of Indonesia. International Journal of Shipping and Transport Logistics, 12 (4), 307-339. https://doi.org/10.1504/IJSTL.2020.108403

23. Hamilton, J. D. (2018). Why you should never use the Hodrick-Prescott filter. Review of Economics and Statistics, 100 (5), 831-843. https://doi.org/10.1162/rest_a_00706

24. Hildebrandt, A., \& Silgoner, M. A. (2007). The Competitiveness Challenge: EU Member States in International Trade. Monetary Policy \& the Economy, 4, 67-88. https://ideas.repec. org/a/onb/oenbmp/y2007i4b4.html

25. Hodrick, R. J., \& Prescott, E. C. (1997). Postwar U.S. Business Cycles: An Empirical Investigation. Journal of Money, Credit and Banking. 29 (1), 1-16, https://doi.org/10.2307/2953682

26. Huggins, R., \& Izushi, H. (2015). The Competitive Advantage of Nations: origins and journey. Competitiveness Review, 25 (5), 458-470. https://doi.org/10.1108/CR-06-2015-0044

27. Korhonen, J., Pätäri, S., Toppinen, A., \& Tuppura, A. (2015). The role of environmental regulation in the future competitiveness of the pulp and paper industry: The case of the sulfur emissions directive in Northern Europe. Journal of Cleaner Production, 108 (1), 864-872. https:// doi.org/10.1016/j.jclepro.2015.06.003

28. Korshenkov, E., \& Ignatyev, S. (2020). Empirical interpretation and measurement of the productivity and efficiency of regions: The case of Latvia. Insights into Regional Development, 2 (2), 549-561. https://doi.org/10.9770/IRD.2020.2.2(4)

29. Kwon, S., \& Motohashi, K. (2017). How institutional arrangements in the National Innovation System affect industrial competitiveness: A study of Japan and the U.S. with multiagent simulation. Technological Forecasting and Social Change, 115, 221-235. https://doi.org/10.1016/j. techfore.2016.10.005

30. Landesmann, M., Leitner, S., \& Stehrer, R. (2015). Competitiveness of the European Economy, No 401, wiiw Research Reports, The Vienna Institute for International Economic Studies, wiiw. Retreived from: https://EconPapers.repec.org/RePEc:wii:rpaper:rr:401 
31. Lin, W., Liu, B., Gu, A., \& Wang, X. (2015). Industry Competitiveness Impacts of National ETS in China and Policy Options. Energy Procedia, 75, 2477-2482. https://doi.org/10.1016/j. egypro.2015.07.232

32. Mazzanti, M., Mazzarano, M., Pronti, A., \& Quatrosi, M. (2020). Fiscal policies, public investments and wellbeing: mapping the evolution of the EU. Insights into Regional Development, 2 (4), 725-749. http://doi.org/10.9770/IRD.2020.2.4(1)

33. Meleo, L. (2014). On the determinants of industrial competitiveness: The European Union emission trading scheme and the Italian paper industry. Energy Policy, 74 (3), 535-546. https:// doi.org/10.1016/j.enpol.2014.06.030

34. Molendowski, E. (2014). The Visegrad Group Countries - Changes in Intra-industry Competitiveness of their Economies During the World Financial and Economic Crisis. Procedia - Social and Behavioral Sciences, 110, 1006-1013. https://doi.org/10.1016/j. sbspro.2013.12.947

35. Negara, S. D. (2018). How labour market policies affect innovation and trade competitiveness. In: Production networks in southeast Asia, 246-270. Routledge. https://doi. org/10.4324/9781315406787-12

36. Ni, G., Xu, H., Cui, Q., Qiao, Y., Zhang, Z., Li, H., \& Hickey, P. J. (2021). Influence mechanism of organizational flexibility on enterprise competitiveness: The mediating role of organizational innovation. Sustainability (Switzerland), 13 (1), 176. https://doi.org/10.3390/ su13010176

37. Pattanasing, K., Aujirapongpan, S., Ritkaew, S., Chanthawong, A., \& Deelers, S. (2021). The impact of dynamic capabilities and dynamic performance measurement on competitive performance: evidence from Thai hotel entrepreneurs. Entrepreneurship and Sustainability Issues, 8 (3), 10-28. http://doi.org/10.9770/jesi.2021.8.3(1)

38. Phillips, P. C. B., \& Sul, D. (2007a). Some empirics on economic growth under heterogeneous technology. Journal of Macroeconomics, 29 (3), 455-469. https://doi.org/10.1016/j. jmacro.2007.03.002

39. Phillips, P. C. B., \& Sul, D. (2007b). Transition modeling and econometric convergence tests. Econometrica, 75 (6), 1771-1855. https://doi.org/10.1111/j.1468-0262.2007.00811.x

40. Phillips, P. C. B., \& Sul, D. (2009). Economic transition and growth. Journal of Applied Econometrics, 24 (7), 1153-1185. https://doi.org/10.1002/jae.1080

41. Porter, M. E. (1998). Competitive Advantage of Nations. New York: Free Press. https://books. google.hr/books?id=onk4QH2rxGIC

42. Porter, M. E. (2011). Competitive Advantage of Nations: Creating and Sustaining Superior Performance. New York: Free Press. https://books.google.hr/books?id=CqZzxAxBpfEC

43. Porter, M. E. (1990). The Competitive Advantage of Nations. Harvard Business Review, 68, 73-93. https://doi.org/10.1007/978-1-349-11336-1

44. Prasetyo, P. E. \& Kistanti, N. R. (2020). Human capital, institutional economics and entrepreneurship as drivers for quality \& sustainable economic growth. Entrepreneurship and Sustainability Issues, 7 (4), 2575-2589. https://doi.org/10.9770/jesi.2020.7.4(1)

45. Radaev, V. (2018). A rise of state activism in a competitive industry: The case of Russian retail 
trade law of 2009. Communist and Post-Communist Studies, 51 (1), 27-37. https://doi.org/10.1016/j. postcomstud.2018.01.001

46. Sato, K., Shimizu, J., Shrestha, N., \& Zhang, S. (2020). A new empirical assessment of export price competitiveness: Industry-specific real effective exchange rates in Asia. North American Journal of Economics and Finance, 54, 101262. https://doi.org/10.1016/j.najef.2020.101262

47. Schnurbus, J., Haupt, H., \& Meier, V. (2017). Economic Transition and Growth: A Replication. Journal of Applied Econometrics, 32 (5), 1039-1042. https://doi.org/10.1002/jae.2544

48. Sichera, R., \& Pizzuto, P. (2019). ConvergenceClubs: A package for performing the phillips and sul's club convergence clustering procedure. R Journal, 11 (2), 142-151. https://doi. org/10.32614/rj-2019-021

49. Škare, M., Radolović, S., \& Tvaronavičienė, M. (2021). Managing the institutional environment and impact on the competitiveness of transitional economies. Entrepreneurship and Sustainability Issues, 8 (3), 504-526. http://doi.org/10.9770/jesi.2021.8.3(32)

50. Skrynkovskyy, R., Kataiev, A., Zaiats, O., Andrushchenko, H., \& Popova, N. (2021). Competitiveness of the company on the market: Analytical method of assessment and the phenomenon of the impact of corruption in Ukraine. Journal of Optimization in Industrial Engineering, 14 (1), 103-110. https://doi.org/10.22094/JOIE.2020.677836

51. Smith, A. (2000). The wealth of nations (R. Reich \& E. Cannan, Eds.; 1776/2000 ed.). Modern Library. https://search.library.wisc.edu/catalog/999905503902121

52. Sun, K. A., \& Lee, S. (2019). Competitive advantages of franchising firms and the moderating role of organizational characteristics: Evidence from the restaurant industry. International Journal of Hospitality Management, 77, 281-289. https://doi.org/10.1016/j.ijhm.2018.07.007

53. Tahir, N., \& Tahir, P. (2019). Does competition explain growth in OECD and BRICS countries? Competitiveness Review, 29 (5), 515-533. https://doi.org/10.1108/CR-10-2018-0063

54. Thazhugal Govindan Nair, S. (2020). Does BRICS partnership really matter in price competitiveness and external sector growth? Competitiveness Review, 30 (5), 577-594. https://doi. org/10.1108/CR-08-2019-0075

55. Toan, N. Q., Tam, N. V., Hai, D. T., \& Quy, N. L. D. (2020). Critical factors affecting labor productivity within construction project implementation: a project manager's perspective. Entrepreneurship and Sustainability Issues, 8 (2), 751-763. http://doi.org/10.9770/jesi.2020.8.2(45)

56. Ulman, S.-R. (2013). Corruption and National Competitiveness in Different Stages of Country Development. Procedia Economics and Finance, 6, 150-160. https://doi.org/10.1016/s22125671(13)00127-5

57. Veiga, P. M., Teixeira, S. J., Figueiredo, R., \& Fernandes, C. I. (2020). Entrepreneurship, innovation and competitiveness: A public institution love triangle. Socio-Economic Planning Sciences, 72, 100863. https://doi.org/10.1016/j.seps.2020.100863

58. Wang, L., \& Gao, Y. (2020). Competition network as a source of competitive advantage: The dynamic capability perspective and evidence from China. Long Range Planning, 54 (2), 102052. https://doi.org/10.1016/j.lrp.2020.102052 
59. Yang, Y. C. (2014). Effect of shipping aid policies on the competitive advantage of national flagged fleets: Comparison of Taiwan, Korea and Japan. Transport Policy, 35, 1-9. https://doi. org/10.1016/j.tranpol.2014.04.003

60. Yu, Z., Li, J., \& Yang, J. (2017). Does corporate governance matter in competitive industries? Evidence from China. Pacific Basin Finance Journal, 43, 238-255. https://doi.org/10.1016/j. pacfin.2017.04.008

\section{Contact information}

Prof. Marinko Skare (corresponding author)

Juraj Dobrila University of Pula

Faculty of Economics and Tourism "Dr. Mijo Mirkovic"

Croatia

E-mail:mskare@unipu.hr

ORCID: 0000-0001-6426-3692

Prof. Matgorzata Porada-Rochon

University of $S_{\text {zrzecin }}$

Faculty of Economics, Finance and Management

Poland

E-mail:malgorzata.rochon@wp.pl

ORCID: 0000-0002-3082-5682

Prof. Sasa Stjepanovic

Juraj Dobrila University of Pula

Faculty of Economics and Tourism "Dr. Mijo Mirkovic"

Croatia

E-mail:sstjepan@unipu.br

ORCID:0000-0003-1938-3681 